\title{
Pengutamaan Bahasa Indonesia di Ruang Publik Pada Nama Tempat Usaha di Jalan Perjuangan Kota Cirebon
}

\section{Itaristanti ${ }^{\mathrm{a}, 1}$}

${ }^{a}$ IAIN Syekh Nurjati, Cirebon, Indonesia

${ }^{1}$ salsabilamashel86@gmail.com

\begin{tabular}{l} 
Article info \\
\hline Article history: \\
Received: 05-02-2020 \\
Revised : 10-04-2020 \\
Accepted: 07-06-2020
\end{tabular}

Keywords:

business signs form and meaning elements prioritizing Indonesian in public areas

A B S T R A C T

Language can be used to communicate in one direction, for example names at the place of business. This study aims to describe the naming of business places in Jalan Perjuangan, Cirebon City, West Java and their relation to efforts to prioritize Indonesian in public spaces. Data collected by listening and documentation. The listening method is realized by a competent, independent listening technique followed by the note taking technique. Documentation is done by taking photos. Data analysis was carried out using the equivalent method with translational disaggregation and distribution methods or the distribution method. The distributional method is carried out using the reverse technique. Meanwhile, the presentation of the results of data analysis is done by the informal method or descriptive method, namely the presentation with ordinary words. The results showed that the naming of business places in the Struggle Street there are shaped: words, phrases, and compounds. Meanwhile, in terms of the language used, there are businesses that speak Indonesian, English, Javanese, Japanese, Chinese, a fusion of Indonesian and English, and a combination of Javanese and English. In addition, inappropriate words were also found, both in Indonesian and English.

Bahasa dapat dilakukan untuk berkomunikasi satu arah, misalnya nama-nama pada tempat usaha. Penelitian ini bertujuan untuk mendeskripsikan penamaan tempat-tempat usaha di Jalan Perjuangan, Kota Cirebon, Jawa Barat dan kaitannya dengan upaya pengutamaan bahasa Indonesia di ruang publik. Data dikumpulkan dengan metode simak dan dokumentasi. Metode simak direalisasikan dengan teknik simak bebas libat cakap yang dilanjutkan dengan teknik catat. Dokumentasi dilakukan dengan pengambilan foto. Analisis data dilakukan dengan metode padan dengan daya pilah translasional dan metode distribusional atau metode agih. Metode distribusional dilakukan dengan teknik balik. Sementara itu, penyajian hasil analisis data dilakukan dengan metode informal atau metode deskriptif, yaitu penyajian dengan kata-kata biasa. Hasil penelitian menunjukkan bahwa penamaan tempat-tempat usaha di Jalan Perjuangan ada yang berbentuk: kata, frasa, dan majemuk. Sementara itu, dari segi bahasa yang digunakan, ada tempat usaha yang berbahasa Indonesia, Inggris, Jawa, Jepang, Cina, perpaduan antara bahasa Indonesia dan Inggris, serta perpaduan antara bahasa Jawa dan Inggris. Selain itu, ditemukan pula kata-kata yang tidak tepat, baik dalam bahasa Indonesia maupun bahasa Inggris.

Copyright $\odot 2020$ Institut Agama Islam Negeri Syekh Nurjati Cirebon. All rights reserved. 


\section{PENDAHULUAN}

Interaksi dalam masyarakat tidak terlepas dari penggunaan bahasa. Karena itulah, keberadaanya begitu penting dalam memenuhi fungsi-fungsinya. Empat fungsi umum bahasa, antara lain sebagai alat berkomunikasi, berintegrasi dan beradaptasi sosial, alat untuk mengekspresikan diri, serta alat kontrol sosial. Terkait dengan fungsinya sebagai salah satu alat dalam berkomunikasi, ada beberapa komponen proses komunikasi yang harus dipenuhi. Komponen tersebut, antara lain penutur, lawan tutur, pesan yang hendak disampaikan, dan media atau alat yang digunakan.

Komunikasi terdiri atas dua macam, yaitu komunikasi satu arah dan komunikasi dua arah. Dalam komunikasi satu arah, tidak terjadi pergantian fungsi peran antara penutur dan lawan tuturnya. Berbeda dengan komunikasi dua arah, penutur dan lawan tutur dapat berganti peran. Salah satu contoh komunikasi satu arah adalah nama-nama pada tempat usaha. Komunikasi ini bersifat memberitahukan. Penuturnya adalah pemilik usaha tersebut. Lawan tuturnya adalah masyarakat yang membacanya. Isi pesannya adalah sesuatu yang berada dalam nama-nama yang tertera itu. Sementara itu, medianya adalah media tulis. Melalui nama-nama itulah, pemilik usaha ingin memberi informasi mengenai barang atau jasa yang mereka perjualbelikan.

Tempat-tempat usaha yang dimaksud dalam penelitian ini meliputi penjual makanan, penjual minuman, barang, dan jasa. Bentuk-bentuk kebahasaan dimanfaatkan untuk menarik minat pembeli. Namun, jika diperhatikan dari aspek pengutamaan bahasa Indonesia di ruang publik, tampaknya masih banyak masyarakat yang belum memahami pentingnya upaya tersebut. Di Jalan Perjuangan Kota Cirebon, masih banyak penamaan tempat usaha yang membingungkan pembaca.

Jazeri \& Maulida (2018) juga menyampaikan bahwa peluang memartabatkan status bahasa Indonesia sebagai bahasa persatuan harus menghadapi berbagai kendala yang justru muncul dari dalam bangsa Indonesia sendiri. Belum ada komitmen yang kuat dari para penutur untuk menempatkan bahasa Indonesia pada tempat yang utama (Anto, dkk., 2019). Padahal, di dalam ruang publik, terdapat pemerolehan informasi dan sistem pemaknaan. Masyarakat akan menyerapnya. Lebih jauh lagi, informasi tersebut akan memengaruhi sikap dan perilaku masyarakat tersebut (Fatmahwati, 2018).

Bahasa Indonesia telah diatur fungsi dan kedudukannya. Kedudukan bahasa Indonesia di Indonesia ada dua, yaitu sebagai bahasa nasional dan sebagai bahasa negara. Dalam kedudukannya sebagai bahasa nasional, bahasa Indonesia berfungsi sebagai lambang kebanggaan nasional, lambang identitas nasional, alat pemersatu berbagai masyarakat yang berbeda latar belakang sosial budayanya, serta alat perhubungan antarbudaya dan antardaerah. Dalam kedudukannya sebagai bahasa negara, bahasa Indonesia berfungsi sebagai bahasa resmi kenegaraan; bahasa resmi pengantar dalam dunia pendidikan; bahasa resmi dalam perhubungan pada tingkat nasional untuk kepentingan perencanaan dan pelaksanaan pembangunan serta pemerintahan; dan bahasa resmi dalam pengembangan kebudayaan dan pemanfaatan iptek.

Dalam undang-undang pun, kegunaan bahasa Indonesia diperjelas lebih lanjut. Undang-Undang Nomor 24 Tahun 2009, Pasal 36 Ayat 3 dan 4 menyebutkan: 
(3) Bahasa Indonesia wajib digunakan untuk nama bangunan atau gedung, jalan, apartemen atau permukiman, perkantoran, kompleks perdagangan, merek dagang, lembaga usaha, lembaga pendidikan, organisasi yang didirikan atau dimiliki oleh warga negara Indonesia atau badan hukum Indonesia.

(4) Penamaan sebagaimana dimaksud pada ayat (1) dan ayat (3) dapat menggunakan bahasa daerah atau bahasa asing apabila memiliki nilai sejarah, budaya, adat istiadat, dan/atau keagamaan.

Karena hal itulah, penelitian mengenai penamaan tempat-tempat usaha ini penting untuk dilakukan sebagai salah satu upaya pemartabatan bahasa Indonesia. Hal ini pun sesuai dengan yang disampaikan Masraeng (2015) bahwa mencermati dari butir Sumpah Pemuda yang ketiga memberikan catatan bahwa bahasa Indonesia harus digunakan untuk kepentingan dalam bidang politik, ekonomi, budaya, dan pendidikan.

Masalah yang akan dikaji dalam penelitian ini, antara lain bentuk penamaan tempat-tempat usaha di Jalan Perjuangan Kota Cirebon serta bahasa yang digunakan dalam penamaan tersebut. Jalan Perjuangan dipilih karena di kawasan tersebut dekat dengan beberapa perguruan tinggi di Cirebon sehingga tempat usahanya pun sangat beragam.

\section{METODE}

Kajian ini merupakan sebuah penelitian kualitatif. Dalam penelitian kualitatif, peneliti membangun pola-pola, kategori-kategori, dan tema-tema dari bawah ke atas (induktif) (Creswell, 2014). Tahap-tahap yang dilalui dalam penelitian ini, antara lain tahap pengumpulan data, tahap analisis data, dan tahap penyajian hasil analisis data. Tahap pengumpulan data dilakukan dengan metode simak (observasi) dan metode dokumentasi. Teknik lanjutan yang digunakan adalah teknik simak bebas libat cakap (SBLC). Sementara itu, metode dokumentasi dilakukan dengan mengambil foto nama-nama tempat usaha tersebut. Validitas data diperoleh secara langsung dari dokumen yang berupa foto dan sumber-sumber laman yang berkaitan dengan tempat usaha tersebut. Jumlah data yang diperoleh adalah 128 nama tempat usaha.

Setelah data terkumpul, tahap berikutnya adalah analisis data. Metode yang digunakan dalam tahap ini, antara lain metode padan dan metode agih. Metode padan adalah metode analisis bahasa yang alat penentunya di luar, terlepas, dan tidak menjadi bagian dari bahasa yang bersangkutan (Sudaryanto, 2015). Teknik dasarnya adalah teknik pilah unsur penentu yang dalam konteks ini berupa daya pilah translasional dan daya pilah ortografis. Daya pilah translasional berwujud bahasa lain sebagai penentunya, sedangkan daya pilah ortografis adalah daya pilah yang penentunya berupa bahasa tulis (Kesuma, 2007). Metode ini disebut pula dengan metode padan ekstralingual yang menghubungkan masalah bahasa dengan hal yang berada di luar bahasa (Mahsun, 2017). Teknik lanjutannya kemudian disebut dengan teknik hubung banding.

Metode analisis data yang kedua adalah metode agih. Jika dipahami dalam literatur Mahsun, metode ini tampak mirip dengan metode padan intralingual. Metode padan intralingual adalah metode analisis dengan cara menghubungbandingkan unsur-unsur yang bersifat lingual, baik yang terdapat dalam satu bahasa maupun dalam beberapa bahasa (Mahsun, 2017). Teknik dasar yang digunakan adalah teknik bagi unsur langsung. Teknik lanjutan yang digunakan 
adalah teknik balik. Tahap terakhir adalah penyajian hasil analisis data. Metode yang digunakan adalah metode deskriptif atau secara spesifik dalam penelitian ini disebut sebagai metode informal. Metode informal, yaitu penyajian hasil analisis dengan menggunakan perumusan kata-kata biasa (Sudaryanto, 2015).

\section{HASIL DAN PEMBAHASAN}

Bahasa memang memiliki fungsi yang beragam. Hal tersebut berkaitan dengan dimensi bahasa yang dikemukakan oleh Thomas dan Wareing. Salah satu dimensi penting dalam bahasa adalah dapat digunakannya untuk berbagai tujuan yang berbeda (Thomas \& Wareing, 2007). Salah satu tujuan atau fungsi tersebut adalah fungsi transaksional. Fungsi transaksional adalah fungsi bahasa untuk mengungkapkan isi (Brown dan Yule, 1996). James Briton pun menyebutnya dengan fungsi transaksional, yaitu fungsi bahasa yang mementingkan pertukaran informasi (Soeparno, 2013). Hal senada juga disampaikan oleh Bennet (1976) yang menyatakan bahwa komunikasi terutama adalah perkara usaha memberitahukan sesuatu kepada pendengar atau menyuruhnya melakukan sesuatu (Brown \& Yule, 1996). Dengan demikian, yang dimaksud dengan fungsi transaksional adalah fungsi bahasa yang digunakan untuk menyampaikan suatu informasi kepada orang lain sebagai lawan tutur atau pendengarnya.

Untuk menyampaikan hal tersebut maka penggunaan bahasa, baik secara lisan maupun tertulis, harus disampaikan secara jelas. Oleh karena itu, elemen bahasa perlu untuk diperhatikan. Elemen tersebut terdiri atas elemen bentuk dan elemen makna. Berdasarkan hal tersebut, dalam penamaan tempat-tempat usaha pun tersusun atas elemen bentuk beserta maknanya. Berikut ini adalah penjabarannya.

\section{Bentuk Penamaan Tempat-tempat Usaha di Jalan Perjuangan Kota Cirebon}

Terdapat banyak jenis usaha yang berada di Jalan Perjuangan Kota Cirebon. Jenis usaha tersebut, antara lain usaha dagang makanan, usaha dagang minuman, beraneka toko, usaha dalam bidang penatu, usaha fotokopi, bengkel, apotek, salon, usaha dalam bidang pelayanan kesehatan, tempat pijat, studio foto, pangkas rambut khusus laki-laki, dealer, tempat kursus, usaha kos, pencucian mobil, biro perjalanan, persewaan barang, pengiriman barang, dan usaha menjahit. Jenis usaha terbanyak adalah usaha dagang makanan. Sesudahnya adalah toko aneka barang, misalnya toko alat tulis, toko yang menjual keperluan hewan peliharaan, toko kosmetik, toko alat-alat listrik, dan lain-lain. Usaha dagang khusus minuman pun juga cukup banyak. Begitu juga dengan usaha fotokopi.

Berdasarkan bentuknya, penamaan tempat-tempat usaha di Jalan Perjuangan Kota Cirebon dapat diklasifikasikan sebagai berikut.

\section{a. Bentuk Kata}

Kata merupakan satuan morfem atau kombinasi morfem yang oleh bahasawan dianggap sebagai satuan terkecil yang dapat diujarkan sebagai bentuk yang bebas; satuan bahasa yang dapat berdiri sendiri (Kridalaksana, 2011). Beberapa tempat usaha di Jalan Perjuangan Kota Cirebon ini menggunakan konstruksi kata untuk menamai usahanya, misalnya dalam contoh berikut. 
(1) IdolaKu

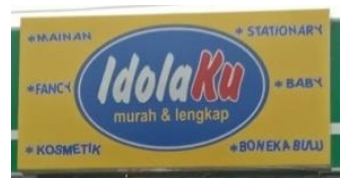

Tempat tersebut merupakan sebuah swalayan yang menjual mainan, alat tulis, perlengkapan bayi, kosmetik, boneka, peralatan makan dan minum, jas hujan, dan lain-lain. Swalayan ini terletak di Jalan Perjuangan Nomor 3 yang berdiri sejak 2017. Nama swalayan ini berbentuk kata dengan tambahan klitik, yaitu kata idola dan klitik $-k u$. Klitik merupakan bentuk terikat yang secara fonologis tidak mempunyai tekanan sendiri dan tidak memiliki ciri-ciri kata karena tidak dapat berlaku sebagai bentuk bebas (Kridalaksana, 2011). Sementara itu, kata idola berarti 'orang, gambar, patung, dan sebagainya yang menjadi pujaan'. Dengan demikian, penamaan dengan kata idolaku ini dilakukan dengan harapan bahwa swalayan tersebut akan menjadi idola masyarakat.

Bentuk penamaan berikutnya berupa kata dengan pengulangan, yaitu kurokuro. Berdasarkan hasil penelusuran melalui laman waralaba ini, kata kuro merupakan akronim dari kata roti dan kata kukus yang kemudian dibalik dalam pengakronimannya, yaitu dari kukus roti. Kata kukus diambil suku pertamanya, yaitu $k u$ - dan kata roti diambil suku yang pertama pula, yaitu ro- menjadi kuro. Kata kuro kemudian diulang menjadi kuro-kuro. Visualisasi papan nama tempat usaha tersebut dapat dicermati berikut ini.

(2) Kuro Kuro

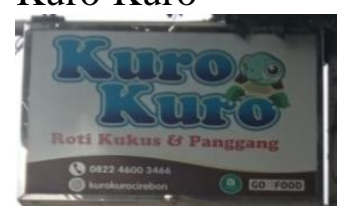

Dalam papan tersebut dicantumkan gambar binatang kura-kura. Bentuk roti yang dijual sebenarnya tidak berbentuk kura-kura. Namun, gambar tersebut dimanfaatkan sebagai asosiasi dari kata dalam bahasa Indonesia kura-kura yang pelafalannya mendekati kuro-kuro.

Usaha ini berjenis waralaba dari Bandung yang saat ini telah mempunyai banyak cabang di beberapa kota, antara lain Jakarta, Bogor, Bekasi, Depok, Cirebon, Banten, Yogyakarta, dan lain-lain. Pemilik usaha ini menjual jajanan roti pandan yang berwarna hijau dengan pilihan kukus atau panggang dengan beraneka macam selai. Di Kota Cirebon, tempat usaha ini terletak di Jalan Perjuangan nomor 51.

Penamaan tempat usaha yang ketiga berupa kata, tetapi dengan permainan bunyi, yaitu kata meenum. Kata ini berasal dari kata minum yang dalam perwujudan penamaannya dipadukan dengan vokal /e/ dalam bahasa Inggris yang dilafalkan /i/. Dalam papan nama, terdapat gambar tempat minum yang berada di atas nama.

(3) MeeNum

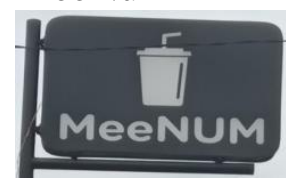

Pemilik usaha ini khusus menjual minuman. Letaknya berada di Jalan Perjuangan nomor 40. Minuman yang dijual beraneka ragam, di antaranya teh yang berjenis thai tea, susu, dan kopi susu. Minuman tersebut disajikan dingin 
dengan campuran yang bermacam-macam, misalnya susu segar dengan gula merah, teh dengan susu, thai tea dengan keju, dan lain-lain.

Sebagian besar tempat usaha memiliki nama kemudian baru diberi keterangan barang atau jasa yang dijualnya. Namun, tidak demikian dengan penamaan tempat usaha berikut. Pemilik usaha langsung menuliskan barang yang dijualnya, yaitu wallpaper.

(4) WALLPAPER

\section{WALLPAPER}

Kata wallpaper berasal dari bahasa Inggris yang berarti 'kertas dinding'. Tempat usaha ini menjual kertas hiasan untuk dinding, misalnya dinding rumah.

\section{b. Bentuk Frasa}

Selain dengan kata, penamaan tempat usaha juga ada yang berbentuk frasa. Frasa adalah gabungan dua kata tau lebih yang sifatnya tidak predikatif (Kridalaksana, 2011). Bentuk inilah yang paling banyak ditemukan pada penamaan tempat usaha. Berikut ini beberapa contoh.

Contoh (5) dan (6) berikut ini merupakan tempat usaha yang bergerak dalam bidang jasa, yaitu jasa mencuci dan menyetrika baju. Penamaan usaha ini banyak menggunakan kata-kata yang menggambarkan kesegaran dan kebersihan, misalnya nama-nama buah, nama warna, atau sifat sesuatu yang bersih. Hal tersebut sesuai dengan usaha yang mereka jalankan, yaitu membersihkan dan merapikan pakaian.

(5) Strawberry Laundry

$$
\text { - Stranowerny Lacendaty }
$$

(6) New BENING Laundry

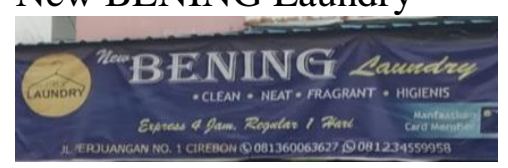

Strawberry Laundry terletak di Jalan Perjuangan nomor 111A, sedangkan Bening Laundry terletak di Jalan Perjuangan Nomor 1.

Tempat usaha berikutnya menjual ayam goreng. Penamaan tempat usaha tersebut menggunakan nama pedagang yang ditambah dengan spesifikasi barang dagangannya, misalnya pada contoh (7), yaitu Ranisa Fried Chicken. Ayam yang dijualnya digoreng dengan balutan tepung. Penamaan usaha sejenis yang lainnya pun dilakukan seperti ini, misalnya Hisana Fried Chicken yang terletak di Jalan Perjuangan nomor 20.

(7) RANISA FRIED CHICKEN

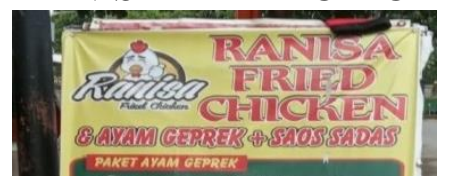

Penjual makanan berikut ini juga menggunakan bentuk frasa dalam menamai tempat usahanya, yaitu Raja Mina Frozen Foods dalam contoh (8).

(8) RAJA MINA FROZEN FOODS 
Tempat usaha yang terletak di Jalan Perjuangan Nomor 24 ini menyediakan aneka makanan beku. Penggunaan frasa frozen foods menunjukkan spesifikasi yang demikian. Sementara itu, raja mina adalah nama. Kata mina berarti 'ikan' (KBBI, 2008: 957), sedangkan raja menunjuk pada sesuatu yang menguasai. Jadi, penggunaan frasa raja mina bermaksud menunjukkan bahwa tempat tersebut menyediakan makanan olahan ikan dan sebagainya dalam bentuk beku yang beraneka ragam.

\section{c. Bentuk Majemuk}

Selain berbentuk kata dan frasa, penamaan tempat usaha di Jalan Perjuangan juga ada yang menggunakan kata yang cirinya mirip dengan kata majemuk, yaitu rumah jahit dalam data (9) berikut ini.

(9) Rumah Jahit Syahkira

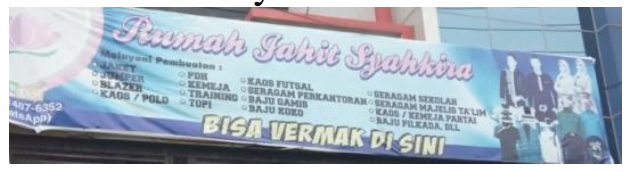

Bentuk majemuk adalah gabungan leksem dengan leksem yang seluruhnya berstatus sebagai kata yang mempunyai pola fonologis, gramatikal, dan semantis yang khusus menurut kaidah bahasa yang bersangkutan (Kridalaksana, 2011: 111).

Dalam penamaan tempat usaha yang menjual jasa menjahit aneka baju tersebut menggabungkan kata rumah dan kata jahit yang dapat sepadan dengan bentuk majemuk rumah sakit. Kata majemuk rumah jahit tersebut kemudian diikuti oleh nama Syahkira. Namun, dalam bahasa Indonesia, bentuk rumah jahit tidak masuk dalam lema KBBI. Lema yang ada adalah rumah busana, yaitu tempat khusus untuk memamerkan dan menjual pakaian.

\section{Bahasa yang Digunakan dalam Penamaan Tempat-tempat Usaha di Jalan Perjuangan Kota Cirebon}

Pada bagian pertama di atas, penamaan tempat-tempat usaha di Jalan Perjuangan Kota Cirebon ditinjau dari bentuk-bentuknya. Sementara itu, berikut ini merupakan analisis beberapa bahasa yang digunakan dalam penamaan tempattempat usaha tersebut. Ada tiga jenis bahasa yang digunakan dalam penamaan ini, yaitu bahasa nasional, bahasa daerah, dan bahasa asing. Ketiga jenis bahasa yang dimaksud, antara lain bahasa Indonesia, bahasa Inggris, bahasa Jawa, bahasa Jepang, dan bahasa Cina. Ada pula penamaan yang memadukan bahasa Indonesia dan bahasa Inggris serta bahasa Jawa dengan bahasa Inggris.

\section{a. Penamaan yang menggunakan bahasa Inggris}

Penamaan tempat usaha di Jalan Perjuangan sebagian besar menggunakan bahasa Inggris. Dari 128 data yang diperoleh, 64 nama atau 50\% menggunakan bahasa ini. Berikut ini beberapa contoh penamaan dengan bahasa Inggris.

Tempat usaha pada contoh di bawah ini menjual parfum atau minyak wangi berbagai merk. Namanya adalah the perfume. Kata perfume sepadan dengan kata parfum dalam bahasa Indonesia yang kemudian bersinonim dengan minyak wangi.

(10) the perfume

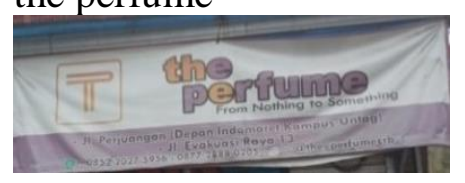


Sementara itu, contoh (11) berikut merupakan tempat jual beli mobil bekas, tukar tambah, baik tunai maupun kredit. Key merupakan nama pemilik usaha, sedangkan motor berarti 'mesin' atau 'motor' (Echols \& Shadily, 2007). Kata tersebut bermaksud menunjuk kepada mobil.

(11) KEY'S MOTOR

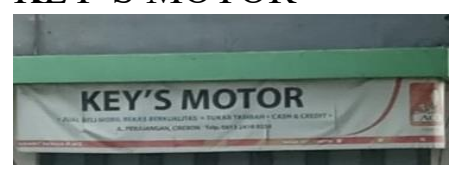

Bahasa Inggris juga sering digunakan untuk memberi nama pada biro perjalanan, misalnya Tazkia Tours \& Travel pada contoh (12).

(12) TAZKIA TOURS \& TRAVEL

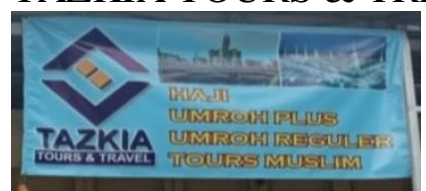

Tazkia merupakan nama pemilik biro perjalanan. Kata tour berarti 'pariwisata', sedangkan kata travel berarti 'perjalanan' (Echols \& Shadily, 2007). Agen ini berarti melayani keduanya, termasuk haji dan umrah.

Selain tempat usaha pada contoh (10), (11), dan (12) di atas, toko yang menjual kebutuhan hewan peliharaan juga menggunakan bahasa yang sama, misalnya pada contoh (13) berikut.

(13) Harry Petshop

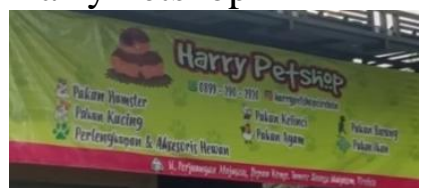

Pola penamaan pada contoh (13) sama dengan contoh (11) dan (12), yaitu berpola frasa bahasa Inggris. Harry adalah nama pemilik, sedangkan petshop berasal dari kata pet yang berarti 'binatang kesayangan' dan shop yang berarti 'toko. Petshop menyatakan jenis usaha yang menjual binatang kesayangan dengan segala keperluannya.

(14) gendhisaudio

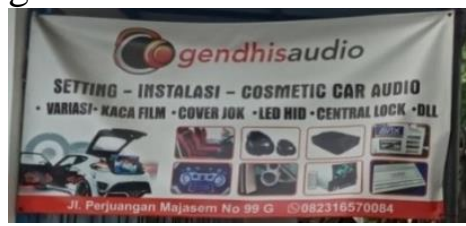

(15) HAMID COPY CENTRE

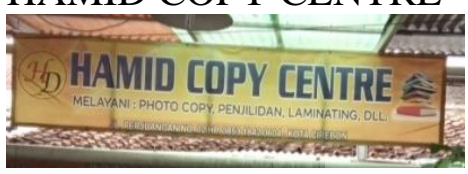

(16) Risna Print Shop

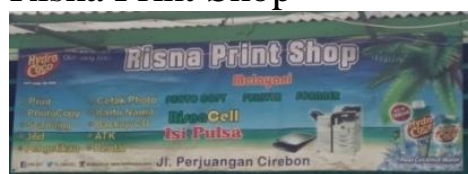

Contoh (14), (15), dan (16) pun sama polanya dengan contok sebelumnya, yaitu mengombinasikan nama pemilik dengan spesifikasi bidang usaha mereka. Gendhis, Hamid, dan Risna adalah nama pemilik usaha. Nama tersebut kemudian dipadukan dengan jenis usaha mereka, yaitu bengkel audio mobil, usaha fotokopi, 
dan usaha yang berkaitan dengan kegiatan cetak-mencetak, misalnya foto, kartu nama, dan lain-lain. kata audio, copy centre, dan print shop. Namun, terdapat kesalahan pada kata centre dalam contoh (15). Untuk menyatakan 'pusat', seharusnya menggunakan kata center, bukan centre.

\section{b. Penamaan yang menggunakan bahasa Indonesia}

Selain menggunakan bahasa Inggris, penamaan tempat usaha juga menggunakan bahasa Indonesia. Namun, penggunaannya tidak lebih banyak dari bahasa Inggris. Dari 128 data yang diperoleh, penamaan dengan bahasa Indonesia sebanyak 51 buah atau 39,8\%. Berikut beberapa contoh penamaan tersebut.

Warung ini menjual nasi bebek, sop daging kambing dan sapi, rawon, serta soto. Namanya Warung Nasi Bebek Khas Madura Ca' Usman. Dari penamaan tersebut menunjukkan bahwa makanan yang dijual adalah makanan khas Jawa Timur. Secara khusus, nasi bebeknya menunjukkan kekhasan dari Madura.

(17) WARUNG NASI BEBEK Khas Madura Ca' USMAN

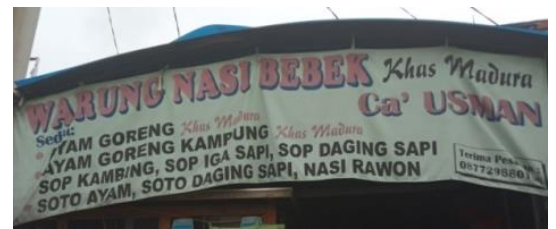

Ca' Usman adalah nama pemilik. Hanya saja, penulisan $c a^{\prime}$ yang benar seharusnya dengan cak. Cak merupakan sapaan kepada orang laki-laki dewasa dalam dialek bahasa Jawa Timur. Berkaitan dengan penamaan tempat usaha, dalam pola frasa bahasa Indonesia, jenis usaha dituliskan terlebih dahulu, baru kemudian diikuti nama pemiliknya. Hal ini berkebalikan dengan pola penamaan dalam bahasa Inggris.

Selain nama warung makan, ada pula klinik dan apotek yang menggunakan bahasa Indonesia, misalnya pada contoh (18) dan (19) berikut. Klinik dan apotek pada contoh (18) ini merupakan tempat usaha yang berada pada satu naungan yang sama. Nama klinik dan apoteknya adalah kita. Penamaan ini menggunakan kata ganti orang pertama jamak.

(18) KLINIK KITA dan APOTEK KITA

(19)
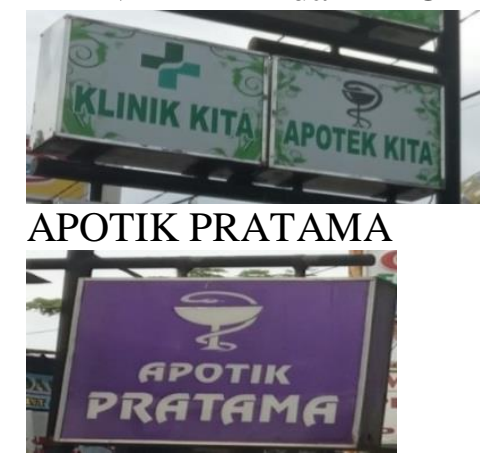

Contoh (19) juga merupakan tempat usaha yang berupa apotek. Namun, terdapat kesalahan dalam penggunaan kata, yaitu apotik. Bentuk yang tepat adalah apotek seperti pada contoh sebelumnya.

Penamaan tempat usaha berikutnya menggunakan bentuk akronim. Kata jupe dalam contoh (20) di bawah ini merupakan akronim dari juara pedas. Akronim tersebut digunakan untuk menamai sebuah kedai. Kata kedai bersinonim dengan warung. Kedai ini menjual makanan dengan rasa pedas, baik nasi, mi maupun makanan lainnya. 
(20) Kedai Jupe

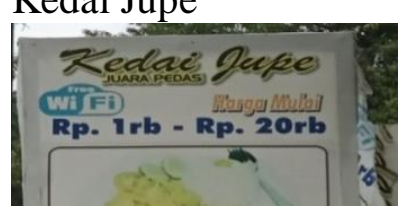

(21)

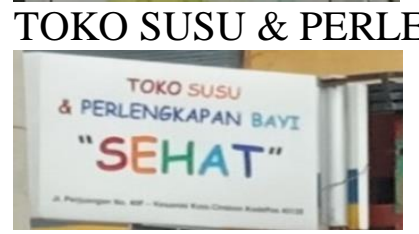

Sementara itu, pada contoh (21) di atas, tempat usaha dinamai dengan kata sehat. Penggunaan kata tersebut untuk menunjukkan adanya hubungan atau pertalian makna yang terkandung di dalamnya dengan jenis usahanya, yaitu toko susu dan perlengkapan bayi.

\section{c. Penamaan yang menggunakan bahasa Jawa}

Bahasa daerah juga dimanfaatkan dalam penamaan tempat usaha di Jalan Perjuangan Kota Cirebon, misalnya bahasa Jawa. Dari 128 data yang diperoleh, persentase penggunaan bahasa Jawa ditemukan sebanyak 4,7\% atau sejumlah 6 nama. Jumlah ini jauh lebih sedikit dibandingkan dengan persentase penggunaan bahasa Inggris dan Indonesia. Berikut ini terdapat empat contoh penggunaan bahasa Jawa yang digunakan dalam penamaan warung makan dan salon.

Warung makan pada contoh (22) di bawah ini menyediakan ayam, bebek, lele, ikan, dan lain-lain. penamaannya menggunakan ungkapan persilahan. Kata mangga berarti 'silakan', sedangkan kersa berarti 'arep' atau 'gelem' (Nardiati, 1993). Namun, pencantuman nama dalam tempat usaha (22) berikut terdapat kesalahan penulisan, yaitu pada kata monggo dan kata kerso.

(22) WARUNG MONGGO KERSO

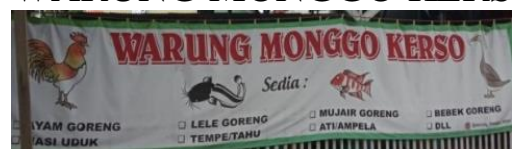

Dalam bahasa Jawa, sebenarnya terdapat alofon [0]. Alofon ini terjadi jika fonem /a/ berdistribusi pada suku kata terbuka (Wedhawati, dkk., 2006). Karena hal itulah, beberapa kata dalam bahasa Jawa, sebenarnya menggunakan fonem /a/, tetapi ketika dilafalkan terdengan seperti bunyi [0]. Bunyi yang terdengar itu kemudian dituliskan apa adanya oleh sebagian orang, misalnya pada contoh (22) di atas.

Sementara itu, pada contoh (23), penggunaan kata warung diganti dengan waroeng yang memadukan penggunaan unsur ejaan lama (ejaan Van Ophuijsen) dalam bahasa Indonesia, yaitu pada fonem /oe/. Kata berikutnya adalah n'deso. Kata n'deso berasal dari kata desa yang kemudian terjadi nasalisasi ketika dilafalkan. Dalam penamaan warung ini, bunyi nasal /n/ tersebut dituliskan menjadi ndeso yang kemudian dimodifikasi menjadi N'deso.

(23) Waroeng N'deso

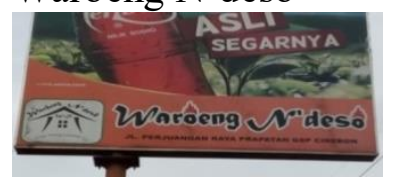




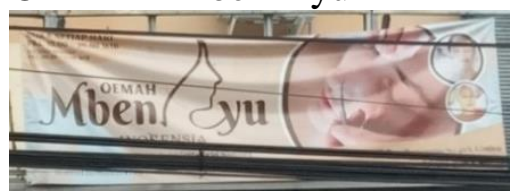

Selain nama warung makan, nama salon pun ada yang menggunakan bahasa Jawa, misalnya pada contoh (24), yaitu Oemah Mben Ayu. Kata oemah berasal dari omah yang dalam bahasa Indonesia berarti 'rumah'. Kata mben berasal dari bentuk ben yang berarti 'biar', sedangkan ayu berarti 'cantik' (Nardiati, dkk., 1993). Jadi, maksud penamaan salon tersebut adalah rumah atau tempat perawatan agar tampil cantik.

\section{d. Penamaan yang menggunakan campuran bahasa Indonesia dan Inggris}

Beberapa tempat usaha berikut ini memadukan bahasa Indonesia dan bahasa Inggris. Penamaan dengan campuran ini ditemukan sebanyak 4 nama atau 3,1\%. Berikut ini beberapa contohnya.

(25) PIJAT REFLEXY Bpk. S. EFENDI

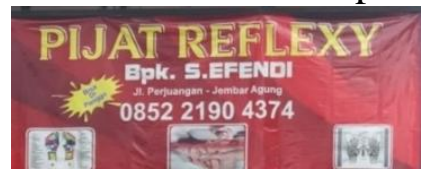

Contoh (25) menggunakan pola frasa bahasa Indonesia, tetapi terdapat kata yang kurang tepat, yaitu reflexy. Bentuk kata tersebut sekilas tampak berasal dari bahasa Inggris. Padahal, dalam bahasa Inggris, sebenarnya kata reflexy itu tidak ada. Perihal yang dimaksud dalam contoh (25) adalah kata reflection. Kata reflection sepadan dengan kata refleksi dalam bahasa Indonesia. Untuk menyatakan maksud bahwa tempat tersebut adalah tempat pijat refleksi, istilah yang tepat dalam bahasa Inggris adalah reflexology (dictionary.cambridge.org/dictionary/english/).

(26) INTAN KELUARGA COPY CENTRE

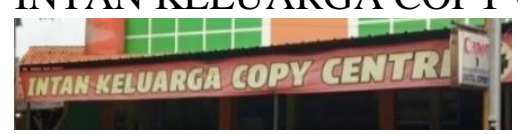

Selain contoh (25), tempat fotokopi pada contoh (26) di atas juga mengombinasikan bahasa Indonesia dan bahasa Inggris. Namun, keberadaan kata keluarga dalam penamaan tersebut membingungkan pembaca. Terdapat dua bagian satuan yang berupa frasa, yaitu Intan keluarga dan copy centre. Penggunaan bentuk Intan keluarga pada contoh di atas mengikuti kaidah frasa bahasa Inggris. Padahal, bahasa yang digunakan pada bagian itu adalah bahasa Indonesia. Dengan teknik balik, bentuk yang benar adalah keluarga Intan. Sementara itu, frasa yang kedua adalah copy centre. Polanya benar, tetapi terdapat kesalahan pada kata centre. Bentuk yang semestinya digunakan adalah center yang berarti 'pusat'.

(27) ARLA PHOTO \& FOTOCOPY

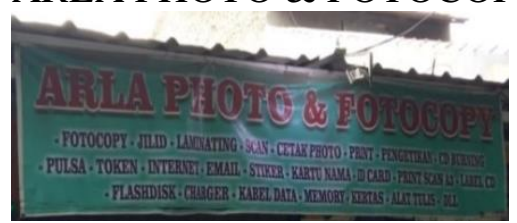

Pada contoh (27) juga terdapat bagian yang salah, yaitu kata fotocopy. Untuk menuliskan fotokopi dalam bahasa Inggris, bentuk yang seharusnya adalah photocopy (Echols dan Shadily, 2007: 428). Percampuran seperti ini mirip dengan 
fenomena Indoglish yang disampaikan Rahardi. Rahardi (2014) menyebutkan bahwa fenomena Indoglish lebih dari sekadar campur kode, melainkan fenomena kebahasaan yang dilatarbelakangi motif-motif tertentu, salah satunya 'prestise' atau gengsi.

\section{e. Penamaan yang menggunakan campuran bahasa Jawa dan Inggris}

Berikut ini juga ditemukan penamaan yang mengombinasikan antara bahasa Jawa dengan bahasa Inggris. Sebagai contoh, ditemukan satu data berikut ini. Persentasenya adalah $0,8 \%$.

(28) Warung Dolan Coffee \& Culinary

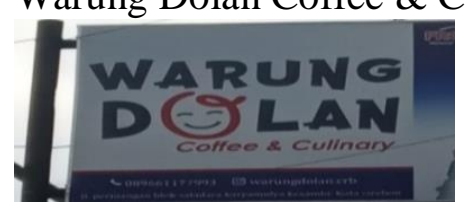

Nama tempat usaha di atas adalah Warung Dolan. Kata dolan berasal dari bahasa Jawa yang berarti 'pergi bermain' (Nardiati, dkk., 1993). Sementara itu, spesifikasi atau jenis usahanya adalah menjual kopi dan beberapa jenis masakan. Hal tersebut ditunjukkan melalui penulisan coffee \& culinary. Kedua kata tersebut berasal dari bahasa Inggris.

\section{f. Penamaan yang menggunakan bahasa Jepang}

Berikut ini terdapat satu contoh tempat usaha yang menggunakan kata yang berasal dari bahasa Jepang.

(29) Ramen Saga

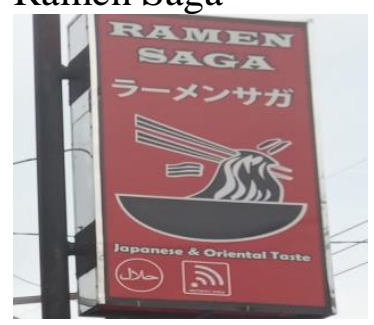

Penamaan tersebut menggunakan kata ramen dan kata saga. Ramen adalah mi kuah khas Jepang yang biasanya berisi sayuran, daging, dan sebagainya. Kata ramen berasal dari bahasa Cina la mian atau la mien yang berarti 'mi yang ditarik' karena dibuat dengan cara menarik adonan tepung terigu sehingga berbentk panjang seperti tali (Supriadi, 2017). Sementara itu, penggunaan kata saga bermaksud untuk menunjukkan bahwa kedai tersebut berwarna merah seperti warna buah saga.

\section{g. Penamaan yang menggunakan bahasa Cina}

Selain bahasa Indonesia, Inggris, Jawa, dan Jepang, ada pula penamaan tempat usaha dengan bahasa Cina yang kemudian langsung tergambar pada jenis makanan yang dijualnya. Dari 128 data, ditemukan satu nama yang berbahasa Cina dengan persentase $0,8 \%$.

(30) O-hayo! dimsum

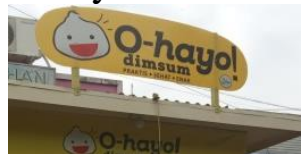

Kata dimsum berasal dari kata dim sum dalam dialek Kantonis atau dianxin dalam bahasa Mandarin. Kata dim sum berarti 'makanan kecil', sedangkan dianxin berarti 'sedikit dari hati' atau 'menyentuh hati' (Sipahutar, 2019). Di dalam KBBI pun dimsum disebutkan merupakan istilah yang berasal dari bahasa 
Cina yang berarti hidangan tradisional Cina yang terdiri atas berbagai jenis makanan, seperti pangsit dan siomai yang dikukus atau digoreng dan disajikan dalam porsi kecil. Hal ini berkaitan dengan arti harfiah kata dianxin tadi.

\section{SIMPULAN}

Berdasarkan bentuknya, penamaan tempat-tempat usaha di Jalan Perjuangan Kota Cirebon terdiri atas tiga bentuk, antara lain bentuk kata, bentuk frasa, dan bentuk majemuk. Berdasarkan bahasa yang digunakan, penamaan tempat-tempat usaha tersebut dapat diklasifikasikan menjadi enam kelompok, yaitu nama yang berbahasa Inggris, berbahasa Indonesia, berbahasa Jawa, berbahasa Jepang, berbahasa Cina, perpaduan antara bahasa Indonesia dengan bahasa Inggris, serta perpaduan antara bahasa Jawa dengan bahasa Inggris. Dalam penamaan tersebut, dijumpai bentuk-bentuk kata yang belum tepat, baik dalam bahasa Indonesia maupun bahasa Inggris. Terdapat pula bentuk penamaan yang berbahasa Indonesia, tetapi berpola frasa bahasa Inggris. Jika mencermati kembali UndangUndang Nomor 24 Tahun 2009, Pasal 3 dan 4 yang telah dikemukakan pada bagian awal, seyogyanya para pemilik usaha mulai memahami aturan penamaan tempat usahanya sehingga dapat menerapkannya dengan tepat. Penerapan aturan penamaan tersebut merupakan salah satu upaya pengutamaan bahasa nasional di tengah derasnya penggunaan bahasa asing di Indonesia.

\section{DAFTAR PUSTAKA}

Fatmahwati, A. (2018). Penggunaan Bahasa Indonesia pada Media Ruang Publik di Kota Pekanbaru. Jurnal Suar Betang, 13(02), 131 - 144.

Anto, Puji, Hilaliyah, H., \& Akbar, T. (2019). Pengutamaan Bahasa Indonesia: Suatu Langkah Aplikatif. Jurnal El-Banar, 02(01), 17 - 24.

Brown, G., \& Yule, G. (1996). Analisis Wacana. Diterjemahkan oleh I. Soetikno. Jakarta: PT Gramedia Pustaka Utama.

Creswell, J. W. (2014). Research Design: Pendekatan Kualitatif, Kuantitatif, dan Mixed. Diterjemahkan oleh Achmad Fawaid. Yogyakarta: Pustaka Pelajar.

Echols, J. M. \& Shadily, H. (2007). Kamus Inggris-Indonesia. Jakarta: PT Gramedia Pustaka Utama.

Jazeri, M., \& Maulida, S. Z. (2018). Hambatan dan Harapan Pemartabatan Bahasa Indonesia. Indonesian Language Education and Literature, 4(1), 52 - 61.

Kesuma, T. M. Jati. (2007). Pengantar (Metode) Penelitian Bahasa. Yogyakarta: Carasvati Books.

Kridalaksana, H. (2011). Kamus Linguistik. Jakarta: PT Gramedia Pustaka Utama. Mahsun. (2017). Metode Penelitian Bahasa. Depok: PT RajaGrafindo Persada.

Masraeng, R. (2015). Diplomasi Bahasa Menjembatani Keragaman Bahasa Daerah dan Pengutamaan Bahasa Bahasa Indonesia. Jurnal Retorika, 1(1), $155-167$.

Nardiati, S., dkk. (1993). Kamus Bahasa Jawa Indonesia I. Jakarta: Badan Pembinaan dan Pengembangan Bahasa.

Rahardi, K. (2014). Bahasa Indoglish dan Jawanesia dan Dampaknya bagi Pemartabatan Bahasa Indonesia. Jurnal Kajian Linguistik dan Sastra, 26(1), $1-21$.

Sipahutar, W. N. (2019). Penentuan Kadar Protein pada Dimsum Siomai dengan Menggunakan Metode Kjeldahl sesuai dengan Standar Nasional Indonesia (SNI). Diakses di http://repositori.usu.ac.id/handle/123456789/21302. 


\section{Indonesian Language Education and Literature e-ISSN: 2502-2261 \\ http://www.syekhnurjati.ac.id/jurnal/index.php/jeill/ \\ Vol. 5, No. 2, Juli 2020, $223-236$}

Soeparno. (2013). Dasar-dasar Linguistik Umum. Yogyakarta: Tiara Wacana.

Sudaryanto. (2015). Metode dan Aneka Teknik Analisis Bahasa: Pengantar Penelitian Wahana Kebudayaan secara Linguistis. Yogyakarta: Sanata Dharma University Press.

Supriadi, S. D. (2017). Ramen bagi Masyarakat Jepang. Diakses di http://repositori.usu.ac.id.

Thomas, L., \& Wareing, S. (2007). Bahasa, Masyarakat, dan Kekuasaan. Diterjemahkan oleh Sunoto, dkk. Yogyakarta: Pustaka Pelajar.

Tim Redaksi Kamus. (2008). Kamus Besar Bahasa Indonesia. Edisi Keempat. Jakarta: PT Gramedia Pustaka Utama.

Wedhawati, dkk. (2006). Tata Bahasa Jawa Mutakhir. Edisi Revisi. Yogyakarta: Penerbit Kanisius. 